\title{
Familiar strangers and stranger-kings: Mobility, diasporas, and the foreign in the eighteenth-century Malay world
}

\author{
Koh Keng We
}

\begin{abstract}
Early modern Malay historiography has been dominated by the history of European trading, colonial empires and local port-polities, often framed along indigenous-versus-foreign lines. Yet, mobility has long been a central feature of this region shaped by commerce, as evidenced by the historical phenomenon of the 'stranger-king'. This study examines the cultural, political and economic impacts of intra-regional migration and diasporic communities in this region, specifically comparing the interconnected histories of the Chinese, Bugis, Arab, and Minangkabau communities in the seventeenth and eighteenth centuries. Locating this history within that of maritime Asia, this study provides a nuanced understanding of the historical Malay world beyond essentialism and communalism. This article highlights why scholars of the Malay world should take into account the important roles of mobility and 'strangers'. It concludes that the Malay world was not a timeless or natural construct, but one whose contours and identity were continually shaped by significant diasporic communities and historical encounters.
\end{abstract}

Early modern Asia was a world of 'strangers', as Felipe Fernandez-Armesto reminds us. ${ }^{1}$ This was all the more so for the early modern Malay world. Long the juncture of maritime and commercial routes between the Indian Ocean and the East Asian seas, the Malay world of Southeast Asia and its fortunes had been shaped by the networks and communities involved in global movements of goods, people, and ideas, and the cosmopolitan environments created by this mobility.

While the study of early modern Asian history has long been dominated by the history of European expansion, more recent scholarship argues for the need to pay greater attention to Asian voices, while avoiding both overly Euro- or Asia-centric perspectives, or Manichaen views of Euro-Asian encounters. There has been a new emphasis rather on the need to understand the structural dynamics of these encounters and engagements in maritime Asia.

Koh Keng We is an Assistant Professor at Nanyang Technological University, Singapore. Correspondence in connection with this article should be addressed to: Kengwe2010@gmail.com.

1 Shifting communities and identity formation in early modern Asia, ed. Felipe Fernandez-Armesto and Léonard Blussé (Leiden: CNWS, Leiden University, 2003); Felipe Fernandez-Armesto, 'The strangereffect in early modern Asia', in ibid., p. 185. 
European commercial expansion into maritime Asia, under the auspices of the East India companies or private traders under various European flags, coincided with the rise of particular diasporic Asian communities in the Malay world. The eighteenth century, which has been labelled by various historians and anthropologists as a Chinese, Bugis, and Arab century, respectively, is a case in point. If we add the Minangkabau and European country traders into this mix, we can see how the eighteenth-century Malay world was shaped by a new configuration of diasporic forces.

This cosmopolitan mix of forces driving regional and global trade and its impact on maritime Asia's political economy was not unique to the eighteenth century. Yet the major diasporic communities - the Minangkabau, the Bugis, the Chinese, and the Arab Sayids - and their networks have mostly been studied along ethnic lines, often belying their diversity and their connections. Furthermore, their purported ethno-cultural characteristics have often been cited as unique factors in explaining their relatively successful economic and political roles in the Malay world.

This study aims not only to compare and contrast the histories of these four diasporic communities in the eighteenth-century Malay world, but also to show how the interconnected expansion of their networks and influence shaped the early modern political economy of the region. Each community represented a particular trajectory of movement and circulation to and within the region, connecting it with other parts of the archipelago and maritime Asia. Analysing these diasporic communities' migrations and adaptations within the same framework allows us to compare and contextualise cultural uniqueness as an explanatory factor in accounting for their strategies and successes. It also reveals how their histories in this region were inextricably intertwined.

Furthermore, as Marshall Sahlins proposed for the premodern Pacific world, and James Fox has shown for the Austronesian, it could be argued that strangeness was an integral part of the kingship and political economy of this world. ${ }^{2}$ This study seeks to demonstrate how, despite the indigenous-versus-foreign dichotomy that has dominant national reconstructions of the Malay world past, mobility and strangeness were crucial elements in the making of the early modern Malay and wider maritime Asian worlds.

\section{Mobility and migration in the making of the Malay world}

The Malay world is an amorphous concept. Geographically, it can be said to encompass the waters and littorals of the Melaka Straits, the southern reaches and islands of the South China Sea and the western waters and littorals of the Java Sea. Within these areas, it was an intermediary zone straddling not only the thalassic and riverine inland zones, with Malay-ness being associated primarily with the downstream environments. Linguistically and culturally, the early modern Malay world was defined by its affinities in these littoral zones, both vis-à-vis the inland regions, and regional geopolitical centres of cultural power and influence in southern India,

2 Marshall Sahlins, 'The stranger-king: Or Dumézil among the Fijians', Journal of Pacific History 16, 3 (1981): 107-32; James J. Fox, "Installing the "outsider" inside: The exploration of an epistemic Austronesian cultural theme and its social significance', Indonesia and the Malay World 36, 105 (2008): 201-18. 
mainland Southeast Asia (notably Ayutthaya), Java (predominantly Majapahit and later the eastern Javanese ports), and China. Thus, in many ways, the early modern Malay world was a 'contact zone' par excellence. ${ }^{3}$

Following Denys Lombard and Claudine Salmon, and Jennifer Gaynor, ${ }^{4}$ rather than imagining the Malay world from a 'mosaic' perspective, which treats the region as part of a broader contiguous set of bounded territories associated with different ethnic identities, it is more important to understand the Malay world as constituted by shifting sets of overlapping sociopolitical, cultural, and economic relationships, that is, from a relational perspective. Rather than clearly defined territorial or geopolitical frontiers, we are concerned more with the structural dynamics and networks underlying the social, political, economic, and cultural formations in a region shaped by mobility and shared maritime and littoral environments.

Mobility was a central theme in such political and sociocultural imaginaries of the Malay world. Works in the corpus of classical Malay literature like the Sulalatus Salatin (Sejarah Melayu), Hikayat Raja-Raja Pasai, and the Hikayat Hang Tuah, as well as the Panji tales, are rife with tales of travelling princes or heroes gaining knowledge and experience in the broader world, overcoming obstacles and challenges, and founding new settlements and polities, or 'playing politics' through their travels. The journeys of these heroes or other important characters in these stories also connected the fortunes of Malay world polities with distant powers in China, Java and India. ${ }^{5}$

The political economy of the Malay world was shaped by its geography: the routes traversing the surrounding seas, the riverine networks linking the littoral zones and interiors, and the overland paths in upstream regions connecting different river systems. ${ }^{6}$ These were the main arteries for the movement of commodities, people, and ideas. The Malay world, as such, was this intermediary coastal zone straddling the sea and the inland/upland areas in Sumatra, the Peninsula, as well as west/northwest Borneo.

Politics in the region revolved around the contest for control of these routes and the nodes connecting long-distance maritime trading networks, merchants moving in

3 Stories like the Hikayat Hang Tuah and histories/genealogies like the Sulalatus al-Salatin provide a 'map' of the '(Malay) world' from the perspective of Melaka, while other Malay court histories provide similar narratives from other regional centres.

4 Denys Lombard and Claudine Salmon, 'Islam and Chineseness', Indonesia 57 (Apr. 1994): 115-32; Jennifer L. Gaynor, 'Liquid territory: Subordination, memory and manuscripts among Sama people of Sulawesi's southern littoral' (PhD diss., University of Michigan, Ann Arbor, 2004).

5 See Henk M.J. Maier: 'The Malays, the waves and the Java Sea', in Looking in odd mirrors: The Java $s e a$, ed. V.J.H. Houben, H.M.J. Maier and W. van der Molen (Leiden: Vakgroep Talen en Culturen van Zuidoost-Azie en Oceanie, Rijksuniversiteit te Leiden, 1992); 'We are playing relatives: Riau, the cradle of reality and hybridity', Bijdragen tot de Taal-, Land- en Volkenkunde (BKI) 153, 4 (1997): 672-98; 'Tales of Hang Tuah: In search of wisdom and good behavior', BKI 155, 3 (1999): 342-61; and We are playing relatives: A survey of Malay writing (Singapore: ISEAS, 2004).

6 Barbara Watson Andaya, To live as brothers: Southeast Sumatra in the seventeenth and eighteenth centuries (Honolulu: University of Hawai'i Press, 1993); Geoffrey Benjamin and Cynthia Chou, Tribal communities in the Malay world: Historical, cultural, and social perspectives (Leiden: IIAS; Singapore: ISEAS, 2002); Freek Colombijn, 'A moving history of Middle Sumatra, 1600-1870', Modern Asian Studies 39, 1 (2005): 1-38; Leonard Andaya, Leaves of the same tree: Trade and ethnicity in the Straits of Melaka (Honolulu: University of Hawai'i Press, 2008). 
more localised or regional circuits between upstream and downstream regions, as well as neighbouring ports, and various local mobile communities like the Orang Laut and other 'tribal' communities moving on the edges of state-systems in the maritime or inland environments. ${ }^{7}$

Further, Malay states, as Geoffrey Benjamin noted, had to 'capture' populations in both land and sea domains in their creations of productive regimes. ${ }^{8}$ They were fundamentally trading polities through their ability to connect different geographic zones and their economic regimes or patterns. He emphasised the interstitial situation' of the Malay states, which was based on the 'presence and possible intensification of tribal populations at both ends - in the forest and on the seas'. The first chiefs or kings, were 'probably sea-people leaders who had moved from individual trading to middlemanship, and settled as land-people on some controlling estuarine site in villages formed around the womenfolk' ${ }^{9}$

A corollary of the region's location at the crossroads of maritime Asia would be its cosmopolitanism and the importance of the 'foreign' in shaping its politics, society, economy, and history. The foreign here denotes different levels, not so much in terms of belonging to territorial states, but vis-à-vis place, polities (as defined by genealogies and relationships), and culture. Rulers in the region often emphasised their foreign origins. Following Sahlins, ${ }^{10}$ kingship and power within this region can be seen as 'foreign' in the way various foundational narratives and court-sponsored histories articulated exogenous origins to emphasise their distinction from local communities. ${ }^{11}$ Rulers emphasised the possession of esoteric knowledge (from the 'outside'), and superior genealogies or other attributes of power associated with distance, strange-ness, and the supernatural. In short, the difference between 'ruler' and 'ruled' was often constructed in terms of distance - geographical, social and cosmological. ${ }^{12}$

Furthermore, political elites in the region adopted foreign religious icons, ideologies, and cosmologies to maintain their distinctiveness from local groups in asserting their claims to authority and legitimacy in local environments, while at the same time adapting them to existing concepts and structures. Foreign traders, adventurers, princes, and so forth became important commercial and political agents for local rulers and elites in dealing both with the 'outside', in connecting them to foreign trading networks or distant ports, or in opening up new frontiers inland or in the maritime zone. ${ }^{13}$

7 See Benjamin and Chou, Tribal communities in the Malay world; Timothy P. Barnard, Multiple centres of authority: Society and environment in Siak and eastern Sumatra 1674-1827 (Leiden: KITLV, 2004); James C. Scott, The art of not being governed: An anarchist history of upland Southeast Asia (New Haven: Yale University Press, 2009).

8 Geoffrey Benjamin, 'On being tribal in the Malay world', in Benjamin and Chou, Tribal communities, p. 42 .

9 Ibid.

10 Sahlins, 'The stranger-king'.

11 On the phenomenon of the stranger-king in the Malay and Austronesian worlds, see Ho Engseng, The graves of Tarim (Berkeley: University of California Press, 2006); James Fox, 'Installing the "outsider" inside'; and Marshall Sahlins, 'Alterity and autochthony: Austronesian cosmographies of the marvelous', HAU: Journal of Ethnographic Theory 2, 1 (2012): 131-60.

12 Mary W. Helms, Ulysses' sail: An ethnographic odyssey of power, knowledge, and geographical distance (Princeton, N.J.: Princeton University Press, 1988); Sahlins, 'The stranger-king'.

13 See, for example, the case of Francisco de Vieira and his relationships with the courts of Makassar and Golconda in Charles R. Boxer, Francisco de Vieira: A Portuguese merchant advenurer in South East 
The stranger-king model does not merely argue for the foreign origins of many ruling families in the archipelago; it underlines a need to re-think power, polity, and kingship in pre-modern societies, and raises interesting questions. Rather than organic outgrowths of a locality, and divided along indigenous-versus-foreign lines, power and politics revolved around the relations between local elites and communities, and powerful foreign individuals and communities. The foreign and the local were locked in a symbiotic and dialectical relationship, with powerful strangers possessing the economic and material means of power, but not socio-cultural capital to achieve legitimacy as rulers. To become kings, these outsiders had to take local royal women as wives, and in so doing, gained genealogical legitimacy to become rulers of the land. In return, powerful local families gained a capable son-in-law and the external networks and resources that he brought. ${ }^{14}$

Not all strangers became kings, however. The ability of individuals and groups within the Minangkabau, Bugis, Chinese, and Arab Sayid networks to become 'kings' locally and regionally depended on being able to transform their economic, social, and cultural capital into legitimate claims within locally constructed fields of hierarchy, authority and power. Between the sixteenth and eighteenth centuries, these understandings of kingship and legitimacy were increasingly embedded in Islam. While we were to see how successively Muslim Minangkabau, Bugis, and Arab Sayid elites were able to seize power and marry into local elite families, or vice versa, the Islamization of these fields of power and the new patterns of Chinese migration and adaptation to the Malay region, saw the new ethnic Chinese migrants beginning to form their own fields and networks of power connected to but relatively autonomous of the local or new stranger-king elites. These fields were continually redefined by new stranger-kings in the Malay world region at different points in time.

Rather than arguing for the uniqueness of any one group, or the pre-eminence of any one dimension (cultural, economic, social or political), this study posits the importance of understanding how these factors and leaders of the abovementioned diasporic communities interacted with each other to shape the history of the early modern Malay world. It argues for the importance of viewing subsequent colonial transformations in the context of these earlier patterns of mobility and interactions in the Malay world.

\section{Towards the coasts, and across the Melaka Straits and beyond: Early modern Minangkabau migrations}

Seventeenth-century Dutch East India Company (Vereenigde Oost-Indische Compagnie; VOC) reports on the littorals and hinterlands of the Melaka Straits noted the important role of migrant Minangkabau communities in the regional political economy. ${ }^{15}$ There were important movements of Minangkabau — from their

Asia, 1624-1667 (The Hague: Martinus Nijhoff, 1967). For the roles of Chinese (at times Muslim) and Arab merchants in the courts of eastern and southeastern Sumatra, Java, and the Dutch port-town of Batavia and central and eastern Java in the seventeenth and eighteenth centuries, see B. Andaya, To live as brothers; Barnard, Multiple centres of authority; Luc Nagtegaal, Riding the Dutch tiger: The Dutch East Indies Company and the northeast coast of Java 1680-1743 (Leiden: KITLV, 1996); and Kwee Hui Kian, The political economy of Java's northeast coast, c.1740-1800: Elite synergy (Leiden: Brill, 2006).

14 On Malay polities, see Ho, The graves of Tarim, pp. 157, 158.

15 Barbara W. Andaya, Perak: The abode of grace (Kuala Lumpur: Oxford University Press, 1979); 
central Sumatran homelands to the east and west coasts as well as upstream areas in Sumatra and the west coast of the Malay Peninsula - between the sixteenth and eighteenth centuries.

Minangkabau migration may have been driven by demographic and land pressures, new economic opportunities in the frontier, the lure of long-distance trade, as well as traditions of migration (merantau), although the reasons remain the object of speculation. ${ }^{16}$ Minangkabaus, as the anthropologist P.E. de Josselin de Jong observed, were 'characterized by a strong wanderlust'. ${ }^{17}$ It was common for Minangkabau men to spend time abroad as traders during their lifetimes. Memories of migration can be found in folklore and oral tradition among Minangkabau communities in eastern Sumatra and the west coast of the Peninsula. Other scholars such as Tsuyoshi Kato believed that merantau was 'deeply rooted in Minangkabau history', and out-migration or merantau was part of the matrilineal system, as a mechanism of village segmentation aimed at resolving the problems of population growth and limited agricultural land. ${ }^{18}$

In seventeenth and eighteenth century Dutch records, Minangkabau migrant communities in eastern Sumatra and the west of the Peninsula are described as being involved in the production and extraction of key commodities for the regional and global trade, from gold mining, the collection of forest produce, and later, pepper cultivation and tin mining. They also traded these commodities between the upstream regions of Sumatra and the Peninsula and their respective littorals. ${ }^{19}$ In the case of eastern Sumatra, they brought textiles, salt, opium and other commodities upstream to the interior. ${ }^{20}$

B. Andaya, To live as brothers; Leonard Andaya, The kingdom of Johor 1641-1728 (Kuala Lumpur: Oxford University Press, 1975); L. Andaya, 'A history of trade in the Sea of Melayu', Itinerario 24, 1 (2000): 87-111; L. Andaya, 'Unravelling Minangkabau ethnicity', Itinerario 24, 2 (2000): 20-43; L. Andaya, 'The search for the "origins" of Melayu', JSEAS 32, 3 (2001): 315-30; Barnard, Multiple centres of authority; Timothy P. Barnard, 'Texts, Raja Ismail, and violence: Siak and the transformation of Malay identity in the 18th century', JSEAS 32, 2 (2001): 331-42; Change and continuity in Minangkabau: Local regional and historical perspectives on West Sumatra, ed. Lynn L. Thomas and Franz von Benda-Beckmann (Athens: Ohio University Center for International Studies, 1985); Christine Dobbin, Islamic revivalism in a changing peasant economy: Central Sumatra 1784-1847 (London: Curzon, 1983); Jane Drakard, A kingdom of words: Language and power in Sumatra (Kuala Lumpur: Oxford University Press, 1999); Elizabeth E. Graves, The Minangkabau response to Dutch colonial rule in the nineteenth century (Ithaca, NJ: Cornell Modern Indonesia Project, 1981); Joel S. Kahn, Minangkabau social formation: Indonesian peasants and the world-economy (Cambridge: Cambridge University Press, 1980); J. Kathirithamby-Wells, 'Myth and reality: Minangkabau institutional traditions in the Rantau', in Thomas and von Benda-Beckmann, Change and continuity in Minangkabau, pp. 121-41; Tsuyoshi Kato, Matriliny and migration: Evolving Minangkabau traditions in Indonesia (Ithaca: Cornell University Press, 1982).

16 See Patrick Edward de Josselin de Jong: 'Dynastic myth in Negeri Sembilan (Malaya)', BKI 131, 3 (1975): 275-310; 'Minangkabau and Negeri Sembilan: Socio-political structure in Indonesia' (PhD diss., Leiden University, 1951); and Ruler and realm: Political myths of Western Indonesia (Amsterdam: North-Holland, 1980), p. 9.

17 P.E. de Josselin de Jong, 'Minangkabau and Negeri Sembilan', p. 9; Kato, Matriliny and migration, p. 22.

18 Kato, Matriliny and migration, pp. 23, 72-117.

19 L. Andaya, 'A history of trade in the Sea of Melayu', and 'Unravelling Minangkabau ethnicity': 20-43; B. Andaya, To live as brothers; Dobbin, Islamic revivalism; Barnard, Multiple centres of authority.

20 B. Andaya, To live as brothers, p. 164. 
Through controlling the production and trade in these commodities in the uplands, migrant Minangkabau communities influenced the fortunes of existing downstream riverine polities and communities. ${ }^{21}$ Port-polity elites in downstream eastern and southeastern Sumatra and the Peninsula sought to co-opt these Minangkabau networks into their respective commercial, political and ritual spheres, through marriage, controlling the supply of key commodities, and through more violent means, such as raiding and warfare.

Yet, the upstream communities were often able to evade downstream rulers, when conditions were not conducive or in the event of the latter's coercion and oppression, by moving between upstream pathways which linked the interior to different river systems downstream. Mobility was an important strategy in resisting exploitation and coercion by the downstream port-polity elites.

Conflict amongst these upstream Minangkabau communities was also endemic as a result of competition for land and access to trade routes and water, often threatening the flow of key commodities to coastal polities dependent on them. ${ }^{22}$ The rulers of these polities often complained of such supply disruptions to their European trading partners. As such, the newer Minangkabau settlement areas in upstream Sumatra and the Melaka hinterland became, in the eyes of European trade partners like the VOC in the seventeenth century, a 'mixed' and 'unruly' frontier. $^{23}$

While early-nineteenth-century European observers like William Marsden had subsumed 'Minangkabau' under the broader rubric of 'Malay', the Minangkabau themselves, both in the central Sumatran homelands and in the frontier, often maintained a distinct identity through their adherence to customs and traditions centred on matriliny, unlike the bilateral social organisations of other regional ethnic communities, as well as through their continued allegiance to the Minangkabau ruler in the central Sumatran highlands. ${ }^{24}$ Kingship played a very important role in the identity politics of the frontier.

Immigrant Minangkabau communities continued to acknowledge the authority of the Minangkabau ruler and Queen Mother in Pagarruyung and other royal centres. They turned to them for assistance and intervention, especially during periods of conflicts and disputes with each other or with downstream polities, and occasionally even requesting for the Minangkabau court to send princes to rule over them. ${ }^{25}$ The Minangkabau ruler and/or his Queen Mother, the Puteri

21 Barnard, Multiple centres of authority, pp. 35-7. See Akira Oki, 'The river trade in central and south Sumatra in the nineteenth century', in Environment, agriculture and society in the Malay world, ed. Tsuyoshi Kato, Muchtar Lufti and Narifumi Maeda (Kyoto: CSEAS, Kyoto University, 1986, pp. 6-7) for Minangkabau movement along the Kampar and Inderagiri rivers, and the extent to which the Inderagiri ruler and the VOC outpost there in the 1660s came to be at the mercy of these upstream producers and traders. For Jambi, see B. Andaya, To live as brothers.

22 See Barnard, Multiple centres of authority, pp. 16-20; B. Andaya, To live as brothers; and Dobbin, Islamic revivalism, for a discussion of agriculture and forest produce collection and trade.

23 Barnard, Multiple centres of authority.

24 De biografie van een Minangkabausen peperhandelaar in de Lampongs: Naar een Maleis Handschrift in de Marsden-Collection te Londen, ed. and trans. G.W.J. Drewes ('s Gravenhage: Martinus Nijhoff, 1961); Nakhoda Muda, Memoirs of a Malayan family, written by themselves, trans. William Marsden (London: Oriental Translation Fund, 1830).

25 See Drakard, Kingdom of words. 
Jamilan, in turn, sought to maintain their influence amongst the frontier communities by sending representatives bearing signs of royal authority and power to collect tribute, mediate in disputes, or in response to requests for arbitration or the nomination of a new ruler. The court of Pagarruyung also sent letters to the VOC government in Melaka to seek the assistance of the Dutch Company on various matters. ${ }^{26}$

Strangers claiming the authority of Pagarruyung on the basis of letters or other objects of power given by the Queen Mother or ruler often appeared in the frontier during crises such as hostilities with downstream rulers, or in the context of infighting. These strangers would lead Minangkabau communities in their resistance and revolts against downstream elites. ${ }^{27}$ The Pagarruyung ruler was even reported to have intervened in the court of Jambi's political struggles on several occasions in the seventeenth and eighteenth centuries. ${ }^{28}$

It was this expanding frontier created by Minangkabau mobility and interactions with the maritime Malay world that provided opportunities for several political entrepreneurs to challenge existing hierarchies and create their own niches, followings, and spheres of influence. Of these, only one was to succeed in establishing his own polity and dynasty, and play an important role in shaping the politics of the eighteenth-century Malay world. His success has to be considered in the broader context of changes brought about by other migrations in the pre-modern Malay world, and the structural dynamics of power and politics in this maritime region.

\section{Bugis-Makassarese migrations: Across the Java Sea}

The Minangkabau migrations in the early modern Malay world coincided with migrations from other parts of the archipelago and maritime Asia. The seventeenth century also saw the westward migrations of Bugis and Makassarese from southern Sulawesi towards the littorals of the Java Sea, the South China Sea, and the Straits of Melaka and Sunda. It saw the creation of another diasporic frontier and sphere, which expanded dramatically through the burgeoning trade between these regions, the growing demand for mercenaries and manpower among rival European groups in the archipelago, as well as escalating troubles and conflicts in the Bugis and Makassarese homelands during this period.

By the early seventeenth century, ties between the royalty in Makassar and those in Jambi had cemented their economic and commercial ties. ${ }^{29}$ As the Dutch and British companies expanded their commercial activities and presence in the first half of the seventeenth century, they turned to itinerant Bugis princes and their followers, fleeing from political conflicts or individual humiliation in their respective homelands. The Bugis prince Arung Palakka, and his entourage, was a case in point. Fleeing from Bone after its conquest by the Makassarese power of

26 Ibid., pp. 73-4, 117-48; L. Andaya, Kingdom of Johor, pp. 250-51.

27 L. Andaya, Kingdom of Johor, pp. 109-14; Drakard, Kingdom of words, pp. 184-92; B. Andaya, To live as brothers, pp. 130-32, 149-52, 162-5, 172-3.

28 B. Andaya, To live as brothers, pp. 160, 163, 166.

29 Ibid., pp. 24, 27. 
Gowa-Tallo, he had entered into the service of the VOC in their campaigns in West Sumatra and against his enemies in southern Sulawesi. ${ }^{30}$

The VOC and its Bugis allies' victory over the Gowa-Tallo Federation, and the revival and expansion of Arung Palakka's influence in the Peninsula and Bone, gave rise to another cycle of conflicts in southern Sulawesi, all of which greatly increased the traffic of refugee princes and their followers to different parts of the Java Sea and the Straits of Melaka, as well as to eastern and southeastern Borneo, and areas east of Sulawesi. These migrations continued into the eighteenth century, largely as a result of the recurring cycles of conflict between rival Bugis and Makassarese polities, as well as the expanding commercial opportunities proferred by the trans-archipelago trade, brought about in no small part by the expansion of European trade in maritime Asia.

The growth of these communities abroad expanded the geopolitical parameters of the Bugis and Makassarese, with diasporic leaders maintaining their relations with their homelands through exchanges of people, gifts, and commodities, and through the direct interventions of Sulawesi rulers in the diaspora. ${ }^{31}$ Conversely, diasporic networks and leaders also intervened in and influenced politics in their respective homelands. Thus, the organisation of Bugis and Makassarese migrant communities reflected homeland hierarchies, and politics in the diaspora at times mirrored those of southern Sulawesi.

The refugee Makassarese and Bugis rulers were initially welcomed in the western archipelago and Java Sea port-polities. ${ }^{32}$ They provided important fighting manpower for these polities, with the possibility of attracting other followers from their respective homelands, as well as marriageable royal kin. ${ }^{33}$ Yet, disputes over their relative status in these centres, and issues of sovereignty and hierarchy, soon resulted in conflicts between hosts and guests, and the collapse of such collaborations, although migrations of such royalty or bands of traders and warriors continued and expanded through the seventeenth and eighteenth centuries, especially to areas dominated by earlier Bugis or Makassarese migrants.

The VOC viewed these movements in the archipelago with concern, as the Bugis and Makassarese not only constituted destabilising influences in their new places of

30 Leonard Y. Andaya, The heritage of Arung Palakka: A history of South Sulawesi (Celebes) in the seventeenth century (The Hague: Nijhoff, 1981), pp. 58-9, 66.

31 Ibid.; Kathryn Anderson Wellen, The open door: Early modern Wajorese statecraft and diaspora (DeKalb: Northern Illinois University Press, 2014). These discourses highlight important parallels with the dynamics of founder-focused ideologies and founder-rank-enhancement ideas often emphasised in studies of Austronesian societies. See Peter Bellwood, 'Hierarchy, founder ideology and Austronesian expansion', in Origins, ancestry and alliance: Explorations in Austronesian ethnography, ed. James Fox and Clifford Sather (Canberra: Australian National University Press, 1996).

32 William Cummings, 'The Melaka Malay diaspora in Makassar, c.1500-1669', JMBRAS 71, 1 (1998): 107-21; Leonard Andaya, 'The Bugis-Makassar diasporas', JMBRAS 68, 1 (1995): 119-38; Heather Sutherland, 'The Makassar Malays: Adaptation and identity c.1660-1790', JSEAS 32, 3 (2001): 397421. See B. Andaya, To live as brothers, on the slave trade between southern Sulawesi and Palembang (p. 96), and marriages between Jambi and Makassar royalty in the late 1670s (p. 104).

33 Bugis and Makassarese migrants, often royalty and their following, also moved from southern Sulawesi to other parts of the archipelago, especially to the east: Sumbawa and Bima, which had become part of the Makassarese imperial network by the early 17th century, were refuges for Makassarese princes; Pasir and Kutai became places of refuge and migration for Wajorese, especially after the rise of Arung Palakka as the pre-eminent figure in southern Sulawesi politics with Dutch patronage in 1671; as did West Sumatra. See Wellen, The open door. 
domicile, providing skilled fighting manpower to contesting polities or elites, but were a potential source of anti-Dutch sentiment in these areas. Disgruntled royalty, such as the Makassarese and Wajorese, could influence the politics of their respective homelands from their new bases. ${ }^{34}$ Further, their archipelagic networks mirrored the VOC's commercial organisation, even if they did not have the same overarching bureaucratic structures.

By the early eighteenth century, sizeable Bugis communities had formed in the frontier or interstitial areas between existing port-polities in the Malay world such as Johor, VOC Melaka, and Perak, in places such as Siantan, Siak, Selangor, and Linggi, often with the permission of existing elites. These communities grew in strength and numbers as they in turn attracted more Bugis and Makassarese migrants, and also through forming alliances with local Minangkabau, Malay, and other communities.

Here, they engaged in the new cultivation and extraction regimes in pepper and tin, feeding the trade in regional centres like Melaka and Johor, while also involving themselves in the trans-archipelagic trade in these and other commodities. ${ }^{35}$ The Bugis communities constituted important nodes for trade flows and networks linking the eastern archipelago with the Malay world region.

As with the Minangkabau, Bugis and Makassarese identities were maintained through preserving their modes of sociopolitical organisation and concepts of hierarchy, authority and power, with some adaptations to the local and regional environments. ${ }^{36}$ These communities and their leaders also continued to look to their respective kingdoms of origin and ruling families in the Bugis homelands for support in the diaspora, and conflicts and traditional enmities in the homelands were replayed abroad. ${ }^{37}$

The convergence of Bugis and Minangkabau migrations to the maritime Malay world in the seventeenth and eighteenth centuries transformed sociocultural, economic and political frontiers, especially around the Melaka Straits. By the early eighteenth century, these communities presented a formidable presence on the frontiers of existing port-polities, especially on the west coast of the Peninsula and in eastern Sumatra, where they began playing important economic and political roles.

\section{Stranger-kings in the making}

The convergence of the Minangkabau and Bugis migrations in the late seventeenth and early eighteenth century Malay world was to bring about important changes in the political landscape and sea-scape. It paved the way for the emergence of new 'stranger-kings' whose connections and contestations with each other and with established centres and ruling families came to define eighteenth-century Malay politics. Their careers, in turn, opened the doors for other new diasporic players in the regional political economy, and new cycles of 'stranger-kingship' in this period.

34 L. Andaya, The heritage of Arung Palakka; Wellen, The open door.

35 Ibid., p. 141; L. Andaya, Kingdom of Johor; Barnard, Multiple centres of authority.

36 Roger Tol, Kees van Dijk and Greg Acciaioli, Authority and enterprise among the peoples of South Sulawesi (Leiden: KITLV, 2000); L. Andaya, Kingdom of Johor, p. 251.

37 L. Andaya, The heritage of Arung Palakka; Wellen, The open door; Barnard, Multiple centres of authority. 
The sudden and spectacular success of Raja Kecik in 1718 in capturing the capital of Johor in 1718, establishing his own polity on the Siak River, and creating his own polity and dynasty in the Malay world, was predicated, first and foremost, on the support he managed to garner in the Minangkabau frontier, especially around Bengkalis. ${ }^{38}$ Letters to the VOC government in Melaka and VOC reports from the time, together with later court histories compiled by the Siak court, spoke of his credentials from Pagarruyung, from the ruler or Queen Mother. ${ }^{39}$

Raja Kecik was part of an older tradition of leadership in the Minangkabau frontier. ${ }^{40}$ As mentioned, in times of crisis or discord within these communities and in their relations with downstream or coastal rulers, individuals would appear carrying letters purported to be from the ruler of the Minangkabau, or the Queen Mother, to lead them against their enemies, or to mediate between them. At times, these envoys even claimed to collect tribute on behalf of the Minangkabau king or the Queen Mother in Pagarruyung. ${ }^{41}$

Yet, Raja Kecik's ultimate success, rather different from that of earlier leaders in the frontier, hinged on his ability to transcend his Minangkabau base, and appeal to the other trading communities in the region, as well as the Orang Laut ('sea people') communities and Orang Kaya (nobility) in the Johor circle, through the rumours and claims purporting that he was the direct descendant of Sultan Mahmud of Johor, who was assassinated in 1699, without an heir. ${ }^{42}$ His claim to be the son of Sultan Mahmud, conceived through supernatural means, held licence in the context of the discontent with the Raja Muda and other members of the Johor royal family at that time, and the defeats the latter had suffered at the hands of the Bugis in the Straits. ${ }^{43}$

However, the difficulties of drawing on and balancing both these communities in the maritime frontier soon became apparent. In the account of Raja Kecik's expedition against Johor recounted in the Siak court chronicles (Hikayat Siak), the Minangkabaus in Bengkalis had become upset at the appearance of the Raja Negara Selat and his Orang Laut followers from the Riau-Lingga archipelago who had come to pay obeisance to Raja Kecik, leading to fighting between the two sides. ${ }^{44}$ Subsequently, when Raja Kecik tried to leave Johor with the booty after his capture of the capital, he was, however, stopped by the Orang Laut who demanded that he leave it behind as a condition of safe passage. ${ }^{45}$

The Raja Negara Selat, the leader of Orang Laut groups in the Strait of Singapore region, subsequently offered his support to the displaced royal family, then led by Bendahara (chief minister) Tun Abdullah, to help drive the Minangkabaus from

38 Barnard, Multiple centres of authority, pp. 55-78.

39 L. Andaya, Kingdom of Johor, pp. 265-76.

40 See L. Andaya, Kingdom of Johor, p. 251; Drakard, Kingdom of words.

41 See Drakard, Kingdom of words; L. Andaya, Kingdom of Johor; B. Andaya, To live as brothers; Barnard, Multiple centres of authority; J. Kathirithamby-Wells, 'Ahmad Shah Ibn Iskandar and the late 17th century "holy war" in Indonesia', JMBRAS 53, 1 (1970): 48-63.

42 The power and legitimacy of the Bendahara family of Johor was continuously challenged at court as well as on the frontiers of the polity because of their role in Sultan Mahmud's assassination in 1699. L. Andaya, Kingdom of Johor, pp. 202-22.

43 L. Andaya, Kingdom of Johor, pp. 222, 265.

44 J. Drakard, Kingdom of words; Barnard, Multiple centres of authority, p. 69.

45 Barnard, Multiple centres of authority, pp. 68-9. 
Johor. ${ }^{46}$ The Orang Laut had also refused to accompany Raja Kecik when he decided to abandon Johor and return to eastern Sumatra. ${ }^{47}$ Yet, they were crucial to his ability to drive away another leader sent by the Pagarruyung court, purportedly, and secure his recognition by the latter, as the ruler of the new Siak polity. ${ }^{48}$

Raja Kecik also seemed to have sought the assistance of the Bugis in his raid on the Johorese capital. ${ }^{49}$ A report by a Portuguese sea-captain who happened to be in Johor during Raja Kecik's attack observed the presence of a contingent of Bugis warriors among his forces. Both the Hikayat Siak and the Tuhfat al-Nafis, histories of the Malay world compiled by the elite families of Siak and Johor, respectively, also recalled that there was contact between Raja Kecik and the Bugis leaders of Linggi prior to the attack, and that he had tried to win them over to his cause. ${ }^{50}$

Raja Kecik's survival and success in creating a new centre on an upstream junction of the Siak River exemplified the need for Malay world elites to straddle the maritime and upstream 'worlds' and their respective communities. His supporters from both downstream and maritime regions assisted him in building the new capital. Nonetheless, he had to come to terms with the Minangkabau and Orang Asli communities there to ensure the success of his new centre.

The straddling of a Malay and Minangkabau identity by Raja Kecik (and his descendants) was, in many ways, a reflection of this ability to create a new polity in the Malay world mould, one that mediated between the maritime zone and the upstream interior, with populations moving and residing in these spaces. His claims to legitimacy rested not only on the possession of sacred objects, purportedly invested by the Minangkabau ruler and Queen Mother in Pagarruyung, but also by virtue of his marriage to the daughter of the deposed Johor ruler, over whom wars were fought following her abduction by some of her royal relatives. ${ }^{51}$

Yet, the government that Raja Kecik created in his new capital, located on the upper Siak, was similar to those of other Minangkabau rantau (frontier areas), with a council - made up of four penghulu, the heads of the four suku or lineages, who later became known as the four datuk - which had the power to appoint a new Sultan 'in the case of death or incapacity'. ${ }^{52}$ The resulting agreement of Raja Kecik with the local communities recognised him as ruler on condition that he had no claims to the land. ${ }^{53}$ Reminiscent of the stranger-kings in the Hawaiian world, Raja Kecik was 'a shark that travels on land' in the way the forces of the sea and maritime world were brought with him upstream, to establish a new centre. In the new arrangement, while he is installed with authority over the land, 'the land itself is not conveyed to him', but 'reserved to its "native owners". 54

46 L. Andaya, Kingdom of Johor, p. 281.

47 Ibid., p. 288.

48 Barnard, Multiple centres of authority, pp. 75-7.

49 L. Andaya, Kingdom of Johor, p. 205; Barnard, Multiple centres of authority, pp. 71, 76.

50 Barnard, Multiple centres of authority, pp. 71, 76.

51 Yusoff Iskandar, Hikayat Siak (Kuala Lumpur: Dewan Bahasa dan Pustaka, 1992); Barnard, Multiple centres of authority, p. 70.

52 Barnard, Multiple centres of authority, pp. 74-6.

53 This was characteristic of Minangkabau kingship in the homeland as well as in the rantau. See Kato, Matriliny and migration.

54 Sahlins, 'The stranger-king or Dumézil among the Fijians': 124-5. 
Raja Kecik's ambitions reached into the Minangkabau frontier, across the Straits of Melaka to the Minangkabau region of Rembau. He sent Raja Khatib, one of his followers, to the area to rule over the Minangkabaus there. Although initially successful in his mission, Raja Khatib was soon displaced by Raja Malewa, a representative sent by the court of Pagarruyung. 55

In trying to carve out his sphere of influence in the maritime Malay world, Raja Kecik also turned to the plethora of diasporic networks in the region. The prominence of Bugis Wajorese, like Haji Hafiz and Daeng Matekko, ${ }^{56}$ and Arabs, like Sayid Uthman and Sayid Umar, epitomised the importance of the sea for Raja Kecik's statebuilding project that straddled the two zones, that of the sea and the rivers that connected to the upstream areas of eastern Sumatra.

The importance of the sea and of straddling the different diasporic networks could still be discerned in the strategies and fortunes of Raja Kecik's descendants, as they competed with each other for the control of the royal centre of Siak. Raja Alam and Raja Mahmud, and their children after them, turned respectively to the sea and to the maritime Malay world to accumulate the followers, experience, wealth, resources, and connections to mount their respective challenges for the centre. ${ }^{57}$

Raja Kecik's usurpation of power in Johor provided the opportunities for the intervention and rise to power of another group of 'stranger-kings'. While Bugis leaders in Linggi and Selangor had weakened the Johorese royal family by attacking Bengkalis and other areas, rebelling against the Raja Muda of Johor's attempts to assert his authority, it was to the Bugis that the Johor royals purportedly turned, in their attempts to recapture Riau from Raja Kecik. Upon the request of members of the Bendahara dynasty in Johor for assistance against Raja Kecik, they drove the latter from Riau and installed Raja Sulaiman as the new ruler. ${ }^{58}$

In return for their assistance, a compact was made between the Bendahara dynasty and the leaders of the Bugis forces, in which Daeng Marewa and Daeng Manompok (the two primary figures in the Bugis camp) were appointed Yang Dipertuan Muda and Yang Dipertuan Tua respectively, with each adopting the title of Sultan, with the power to govern the kingdom on behalf of the newly installed Sultan (Sulaiman). The covenant between the families was reinforced by marriages between the royal family and the families of the Bugis leaders. ${ }^{59}$

These events provide another illustration of the 'stranger-king' dynamic endemic to the maritime Malay world. As much as we can see this as a Bugis seizure of power within the Johor network, it was also imperative for the Sultan and his family to bind these Bugis leaders to them through marriage, and ultimately try to domesticate them within the Johor hierarchy. By 1760, however, Bugis elites had succeeded in outmanoeuvring the Sultan and the Malay nobility, holding the titles of Bendahara, Laksamana, Raja Indera Bongsu, and Temenggong, as well as becoming part of the Sultan's family, establishing themselves as the de facto rulers of Johor. ${ }^{60}$

55 Barnard, Multiple centres of authority, p. 77.

56 Raja Ali Haji, The precious gift (Tuhfat al-Nafis) (Kuala Lumpur: Oxford University Press, 1983).

57 Ibid.

58 Raja Ali Haji, The precious gift; L. Andaya. Kingdom of Johor; Barnard, Multiple centres of authority.

59 The Tuhfat al-Nafis recorded these marriages. See Raja Ali Haji, The precious gift.

60 For traditional roles in the Johor polity, see L. Andaya, Kingdom of Johor, pp. 166-91; For the Bugis 
Furthermore, the Tuhfat al-Nafis, compiled by descendants of one of these Bugis chiefs, showed how this pattern of Bugis stranger-kingship was not unique to Johor. The other members of what was claimed to be the same circle of Bugis leaders extended their network through the Malay world using the same strategy and/or sequence of events, namely through intervening in succession disputes or power struggles, and by marrying into royal families they had assisted to successfully recapture power from rivals.

While payment through money or in kind (often through looting or an agreed share of the wealth and people captured) was often part of the military support of these Bugis elites, the Malay rulers also sought to bind the Bugis leaders through marriage. In turn, the Bugis leaders' wives provided them with access to Malay elite circles, and lent genealogical legitimacy to their new positions within these established polities. In some cases, they even went on to found new polities in the region, as in the case of the founding of Mempawa by Daeng Opu Menambun, a member of the abovementioned family circle of Bugis leaders whose stories are retold through the Tuhfat al-Nafis. ${ }^{61}$

This resulted in the creation of a new Bugis network stretching from Selangor and Linggi in the northwest to Riau in the south, and to Sambas and Mempawa in the east. The brothers of Daeng Marewa were able to replicate his success in Johor in West Borneo, where they assisted the Sultan of Matan against his brother, the Pangeran Agung. In return, the Matan Sultan had married his daughter to Daeng Menambun, the brother of Daeng Marewa. Daeng Menambun was then given the area of Mempawa (to the north of Matan, beside Sambas) as an appanage by his father-in-law, through his wife, Puteri Kesumba, who was the daughter of the Sultan through his marriage with a Dayak princess. ${ }^{62}$ Daeng Kemasi, the youngest brother, was married to Raden Tengah, the sister of the ruler of Sambas, and came to succeed him after the latter's death, creating his own dynasty in the region. ${ }^{63}$

The broader Bugis diaspora played a very important role in the strategic considerations of these new Malay world elites. This was highlighted in the compact between the Malay Sultan and the Bugis warriors, with one article stipulating that 'all Bugis, Makassarese, and inhabitants of Bima and Sumbawa will be delivered to the Bugis in Riau whenever they are captured by the "people of the Straits". At the same time, the Bugis were to have free entry to 'all territories and ports of Johor, without exception'. Similarly, the Bugis, 'since [they] shall live as brothers', shall be allowed to freely leave the lands of Johor. ${ }^{64}$

The power bases of Daeng Marewa and Daeng Manompok centred as much on their respective cohorts of Bugis warriors, as on their control over Bugis populations and areas in the Straits of Melaka. Nevertheless, they also relied on their kinsmen and

capture of power, see Reinout Vos, Gentle Janus, merchant prince: The VOC and the tightrope of diplomacy in the Malay world, 1740-1800 (Leiden: KITLV, 1993).

61 Raja Ali Haji, The precious gift.

62 Raja Ali Haji, The precious gift, pp. 51-2; 'Hikayat Upu Daeng Menambun', in Fritz Schulze, Die Chroniken von Sambas und Mempawah: Einheimische Quellen zur Geschichte West-Kalimantans (Heidelberg: J. Groos, 1991), pp. 38-47.

63 Raja Ali Haji, The precious gift, pp. 67, 332.

64 L. Andaya, Kingdom of Johor, pp. 289-90, 297, 300. 
allies among the Malay nobility. Thus, in the Tuhfat al-Nafis, Daeng Manompok would be accused of plotting with the Malay nobility against his Bugis compatriots. Hence, the relationships among the Bugis chiefs in Johor were by no means always cordial.

Daeng Marewa and members of his family circle in West Borneo also emphasised their ties with the homeland, especially with the centres of Luwuk, Wajo, and Bone. Daeng Marewa sent slaves, booty, and other gifts to the ruler of Bone as tribute, for which contingents of fighting men were sometimes sent in return. Daeng Marewa himself credited the ruler of Bone, toSappewali, for his victories against Raja Kecik, and continued to court the support of the Bone rulers with tribute. ${ }^{65}$ The ruler of Bone considered the Bugis outside southern Sulawesi as his subjects.

Homeland enmities between elites families of rival kingdoms were often re-enacted in the diaspora. Rivalries in Sulawesi were replicated in the western archipelago. The region-wide conflicts with the forces of Raja Kecik also brought the five opu (related to Lamuru, a polity associated with Bone) into contests with other migrant Bugis leaders hailing from Wajo and Makassar, such as Daeng Matekko and Haji Hafiz (Wajo), and Encik Yahya (Makassar), respectively. ${ }^{66}$

Family and kinship ties were also important in the strategies of these Bugis elites. In Daeng Menambun's wars with the upstream polity of Pinang Sekayuk in the interior of Mempawa in West Borneo, his brothers, Daeng Kemasi, the new Pangeran Mangkubumi of Sambas, and Daeng Cellak, the new Yang dipertuan Muda of Riau, both came to his aid. Ties with the wider family in other parts of the archipelago were also maintained through long distance cross-cousin marriages, such as those between the children of Daeng Menambun and those of his uncle, Daeng Biasa, in Batavia. ${ }^{67}$

Thus, the Minangkabau and Bugis-Makassarese migrations to the Malay world, together with the structural dynamics of the region, provided the conditions for the rise of new stranger-kings. Several of these figures were able to draw on the diasporic communities and other opportunities in the maritime Malay world to create new dynasties. Raja Kecik and the Bugis elites in Riau, Mempawa, and Sambas had rather different strategies of expansion and survival, but both groups turned to the sea and the maritime environment for manpower, resources, and wealth. While the new BugisMalay world royalty tapped extensively on Bugis diasporic networks spanning the Java Sea and Malay world region, Raja Kecik and his descendants tapped not so much on the Minangkabau but on various diasporic networks.

The rise of these new elites and their attempts to create new centres opened up opportunities for other outsider communities. Thus, the careers of Raja Kecik and the five Bugis princes coincided with both the growing Chinese and Arab Sayid migrations to the archipelago, notably the influx of Chinese labour, and the prominence of Arab Sayids in the archipelago's port-polities. While there were undoubtedly push factors for such mobility, the stranger-king dynamics of the region played no

65 Ibid., pp. 290-91, 300-301.

66 Wellen, The open door, pp. 123-4; Raja Ali Haji, The precious gift, pp. 81-7.

67 Raja Ali Haji, The precious gift, p. 70. According to this same text, Daeng Rilaga, the father of Daeng Menambun, was the brother of Daeng Biasa, and had visited the latter when he called in at Batavia on his journey westwards. 
small part in the rapidly expanding presence and prominence of the diasporic communities in the eighteenth-century Malay world.

\section{Chinese kongsis: New economies and imperium in imperio}

By the seventeenth century, the Chinese had become an important commercial and political presence in the port-polities. In Palembang, Jambi, and Banten, Chinese merchants, some of them having converted to Islam, held important offices at court. Portuguese, English and Dutch merchants attempting to make headway in the pepper trade of these ports, and also in the broader archipelago trade, regarded the Chinese merchants as both competitors and intermediaries. ${ }^{68}$

They came to play an important role in the interventions of other stranger groups in the political economy of early modern Southeast Asia, namely that of the northern Europeans. Chinese labour, if not capital, was central to the building of the new European port-towns of Manila and Batavia. Chinese merchants were actively courted by the new governments in these towns, and were crucial in bringing in labour, artisans, and materials for the construction, expansion, and infrastructural development of these and later European port-towns. They were also responsible for starting new agricultural projects in the environs of these towns, especially Batavia. They also came to play important roles in connecting these ports with China. ${ }^{69}$

The Manchu conquest of China and subsequent establishment of the Qing Dynasty had an impact on the regional patterns of migration, particular in mainland Southeast Asia. Chinese migration to Southeast Asia was not restricted to insular Southeast Asia or to commerce or labour. Political refugees from southern China moved to Siam, Cambodia, and the Nguyen South in Vietnam, where they participated in commerce as well as agriculture, and their leaders came to play important roles not only in frontier regions, but also at the centre. It was with the support of the Chinese merchant community that Taksin was able to seize power in the vacuum left by the Burmese defeat of Ayutthaya and establish a new dynasty in present-day Thonburi. Several generations of the Mac family in southern Vietnam, refugees during the Qing expansion into southern China, played an important role in securing the frontier with Cambodia on behalf of the Nguyen ruler. ${ }^{70}$

While mid-seventeenth century political disruptions in China led to a decadeslong ban on trade and migration to the southern seas, both soon resumed with renewed vigour after 1683, with the co-optation of the Zheng family and its forces by the Qing state, and the lifting of the ban on southern trade the following year. Despite periodic bans on external trade, and a ban on migration to the south, alongside massacres of the Chinese population in the major port cities of Manila and Batavia, the flows of people and commodities between China and Southeast Asia

68 Léonard Blussé, Strange company: Chinese settlers, mestizo women, and the Dutch in VOC Batavia (Dordrecht: Foris, 1986); B. Andaya, To live as brothers.

69 Blussé, Strange company.

70 Yumio Sakurai and Takako Kitagawa, 'Hatien and Banteay Meas in the time of the fall of Ayutthaya', in From Japan to Arabia: Ayutthaya's maritime relations with Asia, ed. Kennon Breazeale (Bangkok: Foundation for the Promotion of Social Sciences and Humanities Textbooks Project, 1999), pp. 150217; Liam C. Kelley, 'Thoughts on a Chinese diaspora: The case of the Macs of Ha Tien', Crossroads: An Interdisciplinary Journal of Southeast Asian Studies 14, 1 (2000): 71-98. 
continued, especially the southward flow of labour and artisans. The period between 1690 and 1740 was described as the 'heyday of the Junk trade' and of the Chinese in Batavia and its environs. ${ }^{71}$

Yet, it was only after the 1740 massacres in Batavia and the troubles caused by the Javanese wars of succession that we see the first large-scale migrations of Chinese labour to different parts of the Malay world. The extent to which the events in Java contributed to the expanding presence of Chinese migrant labour in Bangka, Riau, and Sambas is not clear. Equally important would be the rise of new elites in each of the abovementioned areas, and their attempts to create new economic bases for their power and position within these areas, and the demand for migrants with the skills needed for the new enterprises. ${ }^{72}$

After the discovery of tin on Bangka, Sultan Mahmud Baharuddin (d. 1757), who had just managed to capture control of Palembang from his brother, was reported to have turned to Chinese labour in the 1730s through the connections of his Chinese Peranakan consort (whom he had married during his exile in Siantan) and her family. ${ }^{73}$ The members of this family were to play important roles in the subsequent supervision of these mines and the imported Chinese labour working them. There was a rapid increase in the number of Chinese miners and mining settlements on the island between 1740 and $1760 .{ }^{74}$ By the late 1750s, the 'overwhelming majority' of the miners on Bangka were Chinese. During this period, Sultan Mahmud was also known to have allowed some followers of his new Mandarese consort to mine tin near Kelabat Bay, although he was ultimately to remove them with the assistance of the Dutch Resident. ${ }^{75}$

71 Anthony Reid, 'Flows and seepages in the long-term Chinese interaction with Southeast Asia', in Sojourners and settlers: Histories of Southeast Asia and the Chinese. In honour of Jennifer Cushman, ed. Anthony Reid and Kristine Alilunas-Rodgers (St Leonards: Allen \& Unwin, 1996); Léonard Blussé, 'Chinese century: The eighteenth century in the China Sea region', Archipel 58 (1999): 107-29.

72 See B. Andaya, To live as brothers, pp. 96-7. See also Blussé, Strange company, p. 48; Kwee Hui Kian, The political economy of Java's northeast coast; Nagtegaal, Riding the Dutch tiger; Willem G.J. Remmelink, The Chinese War and the collapse of the Javanese state, 1725-1743 (Leiden: KITLV, 1994).

73 B. Andaya, To live as brothers, p. 186. Thus, towards the end of 1729, there were already four hundred Bugis mining tin on Bangka, shortly after the discovery of the metal there in the early 1720 s. In the early 1730s, Sultan Mahmud had declared that he was sending a fleet of ships to Siantan, from which his first and 'most loved' Chinese wife hailed, to bring more than a thousand of her 'relatives, good friends, and servants' to Palembang. Five hundred were settled in the Mentuk area of Bangka to increase tin deliveries through closer ties between the producers and the court. As part of this arrangement, the females of this family were exclusively reserved for the Sultan's palace (ibid., p. 188).

74 See B. Andaya, To live as brothers, p. 189. Barbara Andaya suggests that some might have fled the troubles from Java; but the majority were 'new arrivals', from China or from the Chinese overseas communities in Siam, Cambodia, Vietnam, as well as Borneo.

75 In 1737, Sultan Mahmud had married a Mandarese princess from Cenrana in Sulawesi, whom he elevated to senior queen. Her status as favourite saw the arrival of her relatives from Mandar, Makassar, and Banjarmasin, with a number settled on Bangka to mine tin, especially around the Kelabat Bay area, where about a thousand Mandarese were settled by 1745 . Nevertheless, due to disputes with neighbouring communities, especially the Chinese in Mentuk, with complaints of raids by the Mandar and Makassar people, Sultan Mahmud ultimately decided to remove these migrants with the assistance of the Dutch Resident. Although Malays, Bugis and 'mountain people' mined tin into the 1750 s, the Chinese constituted the overwhelming majority of miners. B. Andaya, To live as brothers, pp. 188, 193. 
The establishment of the new Bugis elites in the Riau Islands and West Borneo coincided with the development of new local economies of production on a scale hitherto unseen. The development of the gambier-pepper economy on Bintan in Riau in the 1740s under the second Bugis Yang Dipertuan Muda (viceroy) Daeng Cellak saw the first large-scale migration of Chinese labour to the island to work on these plantations. ${ }^{76}$ Scholars have dated the influx of Chinese labour to Mempawa and Sambas in the interior of West Borneo to mine gold to either the 1740s or the 1760s. ${ }^{77}$

These new migrations were rather different from the older patterns, both in terms of the numbers of people involved, and their organisation and impact on the local Malay political economy and society. Rather than merchants, the majority of the new migrants were labourers. While prior migration had been largely to port-towns and centres, the new settlements were in the frontier regions between downstream and upstream populations. These new migrations were often managed or mediated by established or local-born (Peranakan) Chinese communities. Nevertheless, the movement of Chinese labour to Bangka, Riau, and the interior of West Borneo presented new challenges for the established order.

Rather than networks of merchants reliant on local rulers for protection, these labouring communities, through alliances with Chinese merchants and artisans, formed associations for mutual help, defence, policing, and even commerce. The kongsis and other organisations which were created adopted organisational idioms and institutions based on Chinese religion, rituals, concepts of kinship and hometown ties. These partnerships, alliances, and brotherhoods were as much economic as religious and sociopolitical bodies. They presented a new dimension in the politics of coast-interior and upstream-downstream. Where Islam and political marriages had presented downstream elites with the cultural idioms for co-opting powerful outsiders and their followers, the Chinese kongsis remained perennially apart, with their corporate identity, their access to fighting manpower, and their own commercial networks and routes all enabling autonomy vis-à-vis the downstream rulers. ${ }^{78}$

The rulers of these downstream polities, and the later Dutch colonial government in the early nineteenth century tried, at times, to appropriate Chinese idioms to negotiate with these kongsis, ${ }^{79}$ to little avail. They also frequently used intermediaries such as the Peranakan Chinese or Chinese traders affiliated to them to control the kongsis. ${ }^{80}$ With the growing influx of new migrants and the Chinese populations in the

76 Raja Ali Haji, The precious gift, p. 90.

77 See ibid., pp. 90-91, for a description of 18th-century Riau trade. See also Bingling Yuan, Chinese democracies: A study of the kongsis of West Borneo (Leiden: CNWS, Leiden University, 2000); Mary Somers Heidhues, Golddiggers, farmers, and traders in the 'Chinese districts' of West Kalimantan, Indonesia (Ithaca, NY: SEAP, Cornell University, 2003).

78 See Yuan, Chinese democracies; Wang Tai Peng, The origins of Chinese kongsi (Petaling Jaya: Pelanduk, 1994); Jan Jacob Maria deGroot, Het Kongsiwezen van Borneo: Eene Verhandeling over Den Grondslag en den Aard der Chineesche Politieke Vereenigingen in De Kolonien, met eene Chineesche Geschiedenis van de Kongsi Lanfong ('s-Gravenhage: Nijhoff, 1885); Pieter Johannes Veth, Borneo's Wester-Afdeeling, Geographisch, Statistisch, Historisch, Voorafgegaan door eene Algemeene Schets des Ganschen Eilands, 2 vols. (Zaltbommel: J. Noman en zoon, 1854).

79 Veth, Borneo's Wester-Afdeeling, pp. 367; E.A. Francis, 'Westkust van Borneo in 1832', Tijdschrift voor de Nederlandsch-Indies 4, 2 (1842): 320-22.

80 See B. Andaya, To live as brothers; Mary Somers-Heidhues, Bangka tin and Mentok pepper: Chinese settlement on an Indonesian island (Singapore: ISEAS, 1992); Mary Somers-Heidhues, 'Chinese 
interior, this became increasingly difficult. The labourers in the kongsis doubled as fighting manpower, and they created their own routes and networks to bypass downstream attempts to control their supplies and gold exports. Like the Minangkabau and Bugis, the Chinese were able to remain autonomous of downstream elite circuits of exchange.

By the late eighteenth century, Chinese kongsis formed a nexus of labour, entrepreneurship and capital, alongside their own connections to wider trading networks and interior Dayak communities. The Chinese of the Sambas ulu had created their own downstream channels, through a network of settlements such as Paniraman, Sungai Pinyu, Sungai Raya, Selakau, and Sedau near the mouths of secondary rivers. More importantly, they also came to redefine downstream-upstream relations by 'alienating the Dayak from the Malay', with new links of trade and debt, as well as relations of kinship, tying the Dayak communities to the Chinese, and bypassing the Malay appanage holders. ${ }^{81}$

The Chinese had become imperium in imperio in areas like West Borneo, Bangka, and Riau, but their leaders could not become stranger-kings. They remained instead as perennial strangers in the regional political economy. As such, they remained as the safest allies in any local equation and configuration. They provided manpower and commodities, as well as revenue (in terms of the taxes often levied on them by local rulers and the Dutch), but they could never obtain the social or cultural capital to challenge the legitimacy of the local elites, and to legitimise their own power.

\section{Genealogy, Islam, trade, and raiding: The Hadrami Sayids}

The eighteenth-century Malay world saw the rise to prominence of another important diasporic network, the Hadrami Sayids. ${ }^{82}$ Despite the long history of Arab migration and trade in the region, it was only from the mid-eighteenth century that the Hadrami Sayids came to play important roles in the archipelago's political economy. They were not only traders, but also served as religious teachers and judges, as well as political lieutenants and agents for the region's elites. This was evident in places such as Aceh, Perak, Palembang, Jambi, Siak, Kubu (in West Borneo), Matan, Mempawa, and the north coast Javanese ports. ${ }^{83}$

organizations in West Borneo and Bangka: Kongsi and hui', in Secret societies reconsidered: Perspectives on the social history of early modern South China and Southeast Asia, ed. David Ownby and Mary Somers-Heidhues (Armonk, NY: M.E. Sharpe, 1993), pp. 68-88; 'The first two sultans of Pontianak', Archipel 56, 1 (1999): 273-94.

81 Heidhues, Golddiggers, farmers, and traders, p. 53.

82 The title of Sayid is reserved for particular strata of Hadrami society and migrants, whose genealogies links them to the Prophet Muhammad and his family. Their genealogical status distinguishes them from other 'castes' of Hadrami society, and marriage across these castes are governed by strict rules, which came into contestation in the Indian Ocean realm (originating within Southeast Asia) in the early twentieth century. See Mona Abaza, Hadramaut and the Southeast Asian world: The kingship system, social stratification and migration; a review of literature (Working paper no. 103, Universitat Bielefeld, 1988); Ho, The graves of Tarim; Sumit K. Mandal, 'Finding their place: A history of Arabs in Java under Dutch rule, 1800-1924' (PhD diss., Columbia University, 1994).

83 On the growing importance of Arabs in the 18th century port-polities, see B. Andaya, Perak, p. 165; B. Andaya, To live as brothers, pp. 220-22; Barnard, Multiple centres of authority; Engseng Ho, 'Before parochialization: Diasporic Arabs cast in creole waters', in Transcending borders: Arabs, politics, trade, and Islam in Southeast Asia, ed. Huub de Jonge and Nico Kaptein (Leiden: KITLV, 2002). 
Hadrami Sayids enjoyed a high status in the archipelago and the Indian Ocean world due to their genealogical ties to the Prophet Muhammad. In addition, their knowledge of Arabic and literacy, their commercial ethos, know-how and networks, and their important roles in Sufi networks of religious renewal and education across the Indian Ocean also made them important assets for the port-polity elites. ${ }^{84}$ Their rising prominence in Southeast Asia during this period was partly related to the growing integration of the archipelago into the Islamic ecumene and the networks of reform and transmission in the eighteenth century as well as changing patterns of Indian Ocean trade. ${ }^{85}$ In short, the rise of the Hadrami Sayids in the Malay world was an extension of their prominence in the Indian Ocean littorals by the seventeenth century. Sayids played an important role in the 'civilising' projects of downstream elites in upstream regions, and in the competition between rival elites in the maritime world. ${ }^{86}$

Regional elites also sought to attach Sayids to their ports by marrying their daughters to them. This was in part to connect the genealogical ties of the Sayids to the Prophet to their own genealogies. For the Sayids, this provided access to local and regional elite genealogical networks. ${ }^{87}$ These processes of 'creolisation', in addition to their own diasporic networks, made the Sayids important intermediaries in the Indian Ocean and archipelagic worlds. ${ }^{88}$

Several Hadrami Sayids were to become stranger-kings themselves in the Malay world. The cases of Sayid Ali al-Shihab and his brothers in Siak and Sayid Abdul Rahman al-Qadri in Pontianak serve to illustrate these dynamics. They constituted yet another variation vis-à-vis the careers of Raja Kecik and the Bugis princes. Yet, their careers were also inextricably linked to these new diasporic ruling elites in the Malay world.

There were important parallels in the careers of Sayid Ali and Sayid Abdul Rahman that reflected these broader convergences within the Malay world region and in the archipelago as a whole. Their fathers had gained access to elite circles in the Malay world region via different channels, commercial and religious, respectively. Sayid Uthman, the father of Sayid Ali, was a trader who had entered into the service of Raja Alam, one of Raja Kecik's sons, and assisted the latter in his struggles against his brother (who was also assisted by Arab lieutenants) for the Siak throne. Sayid Abdul Rahman's father, Sayid Habib Husain, had entered the service of the rulers of Matan and Mempawa as adviser (Tuan Sayid) and judge. ${ }^{89}$

84 Azyumardi Azra, The origins of Islamic reformism in Southeast Asia: Networks of Malay-Indonesian and Middle Eastern 'ulama' in the seventeenth and eighteenth centuries (Sydney: ASAA; Allen \& Unwin, 2004).

85 See Azra, The origins of Islamic reformism; Ulrike Freitag and W.G. Clarence-Smith, Hadhrami traders, scholars, and statesmen in the Indian Ocean, 1750s-1960s (Leiden: Brill, 1997); Jonge and Kaptein, Transcending borders; Linda Boxberger, On the edge of empire: Hadhramawt, emigration, and the Indian Ocean, 1880s-1930s (Albany: SUNY Press, 2002).

86 Ho, 'Before parochialization'; The graves of Tarim.

87 See further B. Andaya, Perak, pp. 165, 174.

88 Ho, 'Before parochialization'.

89 For his early career, see Alwi bin Ahmad bin Ismail al-Qadri, 'Hikayat al-Habib Hussein al Qadri', in Naskhah Jawi sejarah dan teks, ed. Yahaya Mahayudin Haji (Kuala Lumpur: Dewan Bahasa dan Pustaka, 1994), pp. 131-5. 
They were subsequently given daughters of elite families in marriage, by virtue of their commercial or religious prowess and authority, and for their genealogical status as Sayids. Both were able to accumulate wealth and followings by turning to the sea, through trading and raiding, after which they came to challenge their new relatives for supremacy. They were able to either seize power in the existing centres or create new ones, largely through maintaining or creating new connections to stranger diasporic networks in the maritime zone.

To assist his Siak overlord, Sayid Ali's father had followed Raja Alam in his exile to Siantan (in the South China Sea), Selangor, and Batu Bahara, and enjoyed his closest confidence, serving as his chief military commander (Panglima Besar) and often conducting negotiations on his behalf. Sayid Ali became a prominent raider himself in the Straits of Melaka under the tutelage of Raja Muhammad Ali, the son of Raja Alam. Operating from his own base in Bukit Batu in eastern Sumatra in the 1780s, he mounted raids on Singora and Bangka in alliance with the expanding Ilanun raiding circuits in that period. ${ }^{90}$

Sayid Ali also became directly connected to the other royal faction, by marrying the eldest daughter of Tengku Musa, a brother of Raja Ismail, the successor of Raja Mahmud. After the deaths of Raja Ismail and his mentor, Raja Muhammad Ali, he was able to seize the Siak centre. With the help of his brothers, Sayid Abdul Rahman, and the Ilanun, he was able to defeat the uneasy coalition between the rival factions of the Siak ruling family, and force its young ruler, Raja Yahya, into exile. He also reorganised the polity around his family, by appointing his siblings as rulers of different polities in the Siak river region. ${ }^{91}$

Sayid Abdul Rahman followed a rather different path to kingship. He had married the daughter of Daeng Menambun, the ruler of Mempawa, two years after arriving with his father, and embarked on an early career of trading to Tambelan, Siantan, and Siak, and ultimately Palembang, where he became successful with the assistance of the Arab trading networks. Due to tensions with the Mempawa royal family arising from his attempts to create his own following in the port-town, he had left Mempawa at the age of 22, making first for Palembang, and ultimately for Banjarmasin, where he impressed the Sultan, who married his sister to him. He was able to conduct a profitable trade in pepper with Mempawa from the port. ${ }^{92}$

With his profits, he had armed his ship ('Tiang Sambong') and began a career of raiding between Bangka and Pasir, on the coast of southeastern Borneo, attacking both European and Asian shipping, gaining such notoriety that his father was said to have disowned him, and alienating his host and brother-in-law in Banjarmasin. From then on, Banjarmasin's rulers refused to allow any Arabs to settle in their realm, a ban that was maintained in their treaties with the Dutch in the midnineteenth century. ${ }^{93}$ Leaving his wife and children in Banjarmasin, he had departed for Mempawa. Although his father had passed away a hundred days before his return,

90 Barnard, Multiple centres of authority, p. 154.

91 On the new circle of power formed by Sayid Ali and his brothers in Siak, Pelalawan, and Bukit Batu after their capture of power in the early 1790s, see Barnard, Multiple centres of authority, p. 160.

92 In Pasir, eastern Borneo, he exchanged with an English trader 238 pikuls of pepper for 14 chests of opium, which he sold for a good price in Banjarmasin. See Veth, Borneo's Wester-Afdeeling.

93 Veth, Borneo's Wester-Afdeeling, pp. 253-5. 
because of the uneasiness among his royal relatives in Mempawa, he had ventured to establish his own base south of Mempawa, around the major river in West Borneo, the Kapuas. With supporters made up of a mix of ethnicities - Bugis, Malay, Arab and others - he had established himself on the island of Pontianak at the strategic confluence of the Kapuas and Landak rivers. ${ }^{94}$

As was typical of new maritime centres, Sayid Abdul Rahman's position in Pontianak was rather precarious, and depended on his ability to maintain relationships with the motley group of traders and raiders who had helped establish the town. In his initial compact with them, they had the freedom to move and leave as they wished. Rather than siblings, his new position as ruler and the survival of his new centre relied on his ability to attract and mobilise the major powers in the maritime world, from his Bugis relatives, even distant cousins like Raja Haji, to the Dutch and English East India companies, and the Chinese kongsis in the interior of West Borneo. The survival and expansion of Pontianak on the west coast of Borneo and in the interior was predicated on Sayid Abdul Rahman's successful utilisation of these forces to his interests and ends.

He was subsequently able to extend his influence and trade into the interior, against the centre of Sanggau upriver, with the assistance of Raja Haji, the Bugis prince from Riau, a distant cousin through Sayid Abdul Rahman's marriage to the Mempawa royal family. It was also Raja Haji who had installed Sayid Abdul Rahman as ruler. ${ }^{95} \mathrm{He}$ also sought to establish ties with the Chinese kongsis in Mandor and Montrado, and with Riau. Many of the older inhabitants of the Kapuas delta and the Landak River, around the new centre of Pontianak, were said to be from Riau and Siak. ${ }^{96}$

Sayid Abdul Rahman was able to convince the Dutch and English East India companies to launch joint attacks against his rivals on the west coast of Borneo in the late eighteenth and early nineteenth centuries. The VOC was crucial to his ability to weaken Sukadana (Matan), and seize control of Mempawa, by installing his son, Syarif Kassim, as ruler. In the early nineteenth century, Syarif Kassim was in turn able to convince the English Company to launch punitive expeditions against Sambas for piracy.

The cases of Sayid Ali and Sayid Abdul Rahman were but two in a broader regional pattern of Arab Sayids coming to prominence as leaders and rulers in the eighteenth and nineteenth-century Malay world. Despite their different paths to kingship, there were important similarities, which represent another permutation in the phenomenon of stranger-kingship in the region. Their genealogical status and association with the Islamic heartland, and in the case of Sayid Abdul Rahman's father, religious learning, differentiated them from the other stranger-kings and influential

94 European reports from Pontianak noted the indebtedness of Sultan Abdul Rahman and his son, Panembahan Kassim of Mempawa, to Arab, Bugis and Chinese traders. The latter came to have a rather poor reputation among the Bugis and the Chinese because of his attempts to make the Bugis pay tolls, and because of his reported murder of a captain of a Chinese junk. His ascension to the throne saw the decline of trade in the port due to the departure of the Bugis. See Heidhues, 'The first two sultans of Pontianak', pp. 280-81, 287.

95 The Tuhfat al-Nafis records Sharif Abdul Rahman as the 'husband of Raja Haji's cousin, Utin Candera Midi'. See Raja Ali Haji, The precious gift, pp. 152-6; Ho, The graves of Tarim, p. 245; and Heidhues, 'The first two sultans of Pontianak': 281.

96 Veth, Borneo's Wester-Afdeeling. 
strangers in the region that we have seen. Nevertheless, their involvement in trade, raiding, and elite family politics in the region saw their fortunes intertwined with other powerful strangers in the maritime trading world of Asia.

\section{Conclusion}

Rather than telling the history of the Malay world as an aggregate of the histories of individual polities, I have attempted to chart its early modern history from the perspective of migration, strangeness, and structural dynamics arising from its geography and location. This comparative analysis of Minangkabau, Bugis, Chinese, and Hadrami Sayid migrations has allowed us to locate this history within a broader transregional and global context, in terms of the connections, flows, and circulations that these migrations created between the Malay world and the Java Sea and eastern archipelago, the South China Sea and the East Asian coasts, and the Indian Ocean and the Hadhramaut and West Asian littorals.

In contrast to the usual practice of studying each diasporic community individually, this approach allows us to contextualise their patterns of mobility, adaptation, and interventions, as well as their impact on the Malay world's socio-scape. Viewed within a single frame, we can see how these migrations overlapped and tapped on one other, and were inextricably linked. This helps to draw important parallels and connections between the histories of different polities, within the Malay world, as well as other parts of maritime Asia.

While these circulations were predicated on earlier trading connections, the intensified scale, scope, and dynamics of the seventeenth and eighteenth-century migrations, and diasporic strategies of adaptation and identity-formation, were very much shaped by early modern Southeast Asian conditions and European commercial expansion, as well as homeland developments. Transregional cultural changes, such as Islamic reformism across the Indian Ocean, also provided an important impetus to such movement.

The expansion of these migrations, especially in the case of the Minangkabau, Bugis, and Chinese, was driven by new economic opportunities through the production of and/or trade in commodities such as agriculture (pepper, gambier, etc.) and mining (tin, gold). These migrations seem to have been larger in scope and scale vis-à-vis those of the Arab Sayid.

Each migration differed in other specific ways. The persistence of matrilineal structures and practices in segments of the Minangkabau frontier in Sumatra and the Malay Peninsula, and the continued appeal of Minangkabau kingship, the Bugis migrations to the western archipelago centring around particular royal or noble leaders, their kin, and their followings, and the emergence of new large-scale ritual-economic-sociopolitical associations underlying the new Chinese communities, provided new social and ideological formations in the Malay world. In contrast, Arab Sayid migration seemed to have followed individual narratives, family histories, and genealogies.

Consequently, each diaspora's modes of adaptation and involvement in local and regional politics differed. While prominent and powerful Minangkabau, Bugis, Arab and (Peranakan) Chinese leaders were able to marry into local royal families, and in the case of a few, to become rulers or contenders for kingship, the Chinese kongsi and 
Minangkabau clans provided distinctive markers and institutions of communal identity resisting such incorporation. Meanwhile, the Bugis maintenance of jati (pure) communities led by princes from southern Sulawesi or other parts of the Peranakan (local-born) networks constituted an important dynamic in local politics in late eighteenth and early nineteenth century Riau.

The diasporic rulers or leaders themselves, despite being recruited into local royal hierarchies and circles through marriage, maintained close ties with their respective homelands and community networks across maritime Southeast Asia. Their continued circulation between their homelands and the Malay world provided the basis for the maintenance of distinct identities. At the same time, the various diasporas often worked with each other in ways that complemented their respective strengths and weaknesses, and their expanding roles in the Malay world were inextricably interlinked.

In this way, each of these diasporas connected the Malay world to different parts of the archipelago and beyond, to the Indian Ocean and South China Sea littorals, hence a comparative study such as this provides new ways of framing Malay world and Southeast Asian history in the early modern period. The eighteenth century saw important changes in the migration patterns of the Minangkabau, Bugis, Arabs and Chinese, and their impact on the Malay world. Their importance can only be fully understood, however, in terms of their interactions with other diasporic configurations, such as those of Dutch and British East India companies, European and later American country traders, and the Armenians and Parsees, to name but a few, in a maritime world shaped by mobility and cosmopolitanism.

The diasporic configurations in the eighteenth century provided the thread in the writing of a regional history, intertwining the histories of polities like Johor, Siak, Perak, Selangor, and West Borneo. The migrations and circulations that transformed the Malay world region in the seventeenth and eighteenth centuries illuminate the region's subsequent history. Rather than a sudden and foreign disruption of traditional societies vis-à-vis a glorious indigenous past, colonialism needs to be understood in the context of these earlier outsider interventions and the mobility, strangeness, and shifting identify-formations that were part and parcel of Southeast Asian history.

The Malay world, as such, was not a timeless or natural construct whose coherence and unity was shattered by European colonial interventions in the early modern period and in the nineteenth century, but a region whose identity and history were continually shaped by historical encounters, exchanges, and intermixing between the local and the foreign in ways that were to persist until the mid- and late nineteenth centuries, with the creation of the new colonial regimes in the region. While this, too, represented yet another permutation in the foreign-local interactions, and the rise of new outsider groups, it was to irrevocably change the place of the foreign in the imagination and articulation of local identities and in writing the history of the Malay world. 